\title{
Domestic and Foreign Institutional Investors' Investment in IPOs
}

\author{
Suman Neupane ${ }^{1}$ \\ Department of Accounting, Finance and Economics, Griffith Business School, Nathan campus, Griffith \\ University, Nathan QLD 4111, Australia \\ Email: s.neupane@griffith.edu.au \\ Tel: +61-737-353500; Fax: +61-737-353719 \\ Biwesh Neupane \\ Department of Accounting and Finance, University of Strathclyde, Scotland G4 OQU, United Kingdom \\ Email: biwesh.neupane@ strath.ac.uk \\ Krishna Paudyal \\ Department of Accounting and Finance, University of Strathclyde, Scotland G4 OQU, United Kingdom \\ Email: krishna.paudyal@strath.ac.uk \\ Tel: +44 1415482894

\section{Chandra Thapa} \\ Department of Accounting and Finance, University of Strathclyde, Scotland G4 OQU, United Kingdom \\ Email: chandra.thapa@strath.ac.uk \\ Tel: +441415483891
}

\begin{abstract}
The regulatory provisions in India ensure that IPO investors are able to observe the participation levels of other subscribers prior to their own subscription decisions. This should reduce the information asymmetry between the foreign institutional (FIIs) and domestic institutional investors (DIIs). We argue that because of this setting we should observe less difference in their investment patterns and performance. Our results, however, show that (a) FIIs subscribe to IPOs more aggressively than DIIs; (b) DIIs have better IPO selection ability than FIIs; and (c) in the post-listing period, FIIs reduce their IPO holdings more extensively than DIIs. FIIs reduce their post-listing holdings especially in firms that are smaller, younger, have higher stock volatility while increasing on stocks with higher returns, indicating that FIIs chase hot markets. Overall, in spite of transparency-enhancing regulations, the investment patterns of FIIs and DIIs differ significantly.
\end{abstract}

JEL Classification: G15, G24, G32

Keywords: Information asymmetry, Indian IPOs, Domestic institutional investors, Foreign institutional investors.

\footnotetext{
${ }^{1}$ Corresponding Author
} 


\section{Introduction}

Recent years have witnessed growing foreign portfolio investments into emerging equity markets, potentially driven by reduced restrictions in capital mobility and improved information flow. Yet, only a few dimensions of foreign portfolio investments have been examined. One particular strand of literature investigates the investment preferences and performances of foreign institutional investors relative to domestic investors. For example, Ferreira and Matos (2008) show that while domestic institutional investors (DIIs henceforth) and foreign institutional investors (FIIs henceforth) share some common investment preferences, they also exhibit substantial differences. Some studies also document that FIIs exhibit superior performance relative to DIIs on account of their investment experience and expertise (see Grinblatt and Keloharju, 2000; Seasholes, 2000). On the other hand, Kang and Stulz (1997) and Choe et al. (2005) suggest that DIIs perform far better than FIIs, especially because of their informational advantage in the home markets. These findings are, however, based on the analysis of investments in secondary equity markets. No study, to our knowledge, has compared the investment patterns of DIIs and FIIs at the time of initial public offerings (IPOs). This distinction is important because investors are likely to have access to more information in secondary markets (particularly due to mandatory disclosure requirements, analysts' coverage, and the wider investor-base of listed firms) than in IPO markets. This paper aims to fill the void in the literature by comparing the investment patterns of FIIs and DIIs in IPO markets.

Given the paucity of publicly available information on IPO firms, DIIs are likely to be better informed investors than FIIs, since they have the advantage of local knowledge and familiarity with domestic firms. This suggests that FIIs face higher investment risks and therefore should participate in fewer IPOs. They are also exposed to a higher adverse selection 
risk, potentially leading to a lower average return as they have to depend on limited information to distinguish between 'good' and 'bad' IPOs. However, such differences between FIIs and DIIs should be significantly less in the context of the Indian IPO market. From the investors' perspective, the Indian IPO market is much more transparent than other markets, since the regulations require the stock exchanges to disclose subscription levels of other investors on a daily basis during the IPO subscription period. ${ }^{2}$ FIIs should, therefore, be as informed as DIIs, through extracting information from the real-time participation activities of DIIs, and be able to participate as actively as DIIs in IPO subscriptions. Consequently, there should be no significant differences in the ability of FIIs and DIIs to distinguish between the 'good' and the 'bad' IPOs in the Indian IPO market.

There are several features of the Indian IPO market that are both unique and relevant for a comparative analysis of the participation of FIIs and DIIs. Indian IPO firms are required to allocate quota for three investor categories: institutional (50\%), non-institutional (15\%) and retail investors $(35 \%))^{3}$ The IPO process is very transparent, since the information on the subscription of various investor categories is publicly available at the time of the offering. Such information is published daily by stock exchanges until the closing date of subscription. This suggests that investors wishing to participate in the offer can find out the demand pattern of other investors

\footnotetext{
${ }^{2}$ The Indian IPO market has become even more transparent in recent years, as the firms which are going public are required to acquire and disclose their quality ratings. Similarly, trading activities in grey markets provide an opportunity to gather the market value of the IPOs before the closing date for subscription. See Neupane and Poshakwale (2012) for further discussion on the transparency of Indian IPO markets.

${ }^{3}$ Large investors such as commercial banks, mutual funds, venture capital funds, and insurance companies who are registered with the SEBI are considered to be institutional investors. Retail investors are those who can bid up to a value of INR 100,000 in the offering. All other investors are considered to be non-institutional investors.
} 
before making their own decisions. ${ }^{4}$ The IPO pricing and allocation mechanism in India resembles a uniform auction price similar to the 'Open IPO' used by WR Hambrecht in the US. ${ }^{5}$ This process allows the underwriters to set the offer price within the advertised price range. Underwriters do not have any discretion in share allocation and subscribers receive their allocation on a pro rata basis. Further, underwriters neither undertake any market stabilization activities nor impose penalty bids both of which are fairly common in the US (see Aggarwal, 2003).

The key foundation of this paper rests on the fact that, owing to the transparent IPO process, both FIIs and DIIs should be able to observe the demand of various investor categories before submitting their own subscriptions. Both types of investors should be able to extract information from other investors' activities. Given the transparent nature of the process, we should not expect any significant difference in the investment patterns (e.g. participation in IPOs, rate of returns, and post-IPO holdings) of FIIs and DIIs. To test this prediction, we address three empirical issues, using a sample of IPOs listed on the Bombay Stock Exchange (BSE) and/or National Stock Exchange (NSE). First, the determinants of DIIs' and FIIs' subscriptions at the time of the IPO are examined by drawing economic reasoning from literature on both IPOs and institutional holdings. Second, we examine the impact of the quality of IPOs, measured by the initial as well as the immediate post-listing returns, on the participation of DIIs and FIIs. Finally,

\footnotetext{
${ }^{4}$ Appendix B-1 (which we also use to demonstrate how we calculate the institutional subscription variable) shows this information for one of the sample companies.

${ }^{5}$ Prior to 2006, the Securities and Exchange Board of India (SEBI) allowed the use of a modified form of book building mechanism in which allocation in the institutional investor category was discretionary. Thus, some of our sample firms were issued under this regime. Moreover, firms wishing to go public are also allowed to use fixed pricing if they do not meet the requirements for the book building/auction mechanism. However, since we are unable to track the participation of institutional investors in these IPOs, we exclude them from our analysis.
} 
we examine the flipping patterns of DIIs and FIIs, by analyzing their holdings in the immediate post-listing period. This analysis shows us how DIIs and FIIs adjust their holdings in the postIPO period.

Our analysis reveals three key findings. First, at the time of the offering, FIIs subscribe more heavily than DIIs. FIIs' subscription is, on average, almost $30 \%$ higher than that of DIIs' (3.12 times vs. 2.40 times the number of shares offered). FIIs also seem to subscribe to the IPOs that are avoided altogether by DIIs. Analysis of the determinants of IPO subscription shows that both DIIs and FIIs prefer firms that are larger, less closely held by insiders, have large cash holdings and appear to be positively influenced by recent market returns. On the other hand, market volatility at the time of the offer appears to dissuade only DIIs, and not FIIs, from investing in Indian IPOs.

Second, both DIIs' and FIIs' subscriptions have a positive relation to the quality of IPOs, measured by initial and immediate post-listing returns. However, when both DIIs' and FIIs' subscriptions are included in the same equation, the influence of the former's subscriptions subsumes that of the latter. DIIs' subscription appears to be far more measured and informed than that of FIIs. This implies that in spite of the transparency of the IPO process, DIIs seem to have superior information to FIIs, possibly reflecting the value of local knowledge.

Finally, we find that institutional investors in general reduce their holdings in IPOs in the immediate post-listing period. ${ }^{6}$ This reduction is more prominent in cold (negative initial return) than in hot (positive initial return) IPOs. FIIs reduce their holdings significantly more than DIIs.

\footnotetext{
${ }^{6}$ Since Indian firms are required to submit their shareholding structure on a quarterly basis, we examine domestic and foreign institutional holdings at the end of the first four quarters after the date of listing. Since institutional holdings remain steady beyond the first quarter, we focus primarily on holdings at the end of the first quarter after listing. Section 3.2 discusses quarterly holdings data.
} 
Further, DIIs reduce their holdings considerably more in hot IPOs, while FIIs appear to do the same in cold IPOs. In the post-listing period, FIIs adjust their position by gravitating towards mature and better cashed up as well as those with better stock returns and lower volatility. Since FIIs reduce their holdings in cold IPOs and increase their holdings in stocks with better stock returns, the evidence is consistent of them being momentum and return chasing investors, as noted in Grinblatt and Keloharju (2000).

This study makes three major contributions to the literature. First, to the best of our knowledge this is the first study to investigate the investment patterns of DIIs and FIIs in the context of IPOs. As such, this work extends the literature on investment behavior of DIIs and FIIs (Ferreira and Matos, 2008 and Grinblatt and Keloharju, 2000) and reveals that although they have several common preferences, their IPO investment strategies differ. Second, this study also adds to the investment behavior literature of DIIs and FIIs in an informationally transparent context where the concern of information asymmetry is lower than in other IPO markets (Kang and Stulz, 1997 and Choe et al., 2005). Even in a relatively transparent Indian IPO market, where FIIs and DIIs have access to similar information, their trading patterns and priorities are different. FIIs exhibit momentum and return chasing behavior, while DIIs appear to follow contrarian trading strategies. Finally, our study shows that although regulators can influence the level of transparency of the IPO process, the value of other externalities (e.g. the local knowledge possessed by DIIs and the enhanced access to superior expertise and extensive experience of FIIs) still influence the investment patterns and security selection abilities of institutional investors.

The remainder of this paper is organized as follows: Section 2 discusses the related literature and develops our testable hypotheses. Section 3 describes the data and presents the 
descriptive statistics. Sections 4, 5 and 6 present the empirical evidence. Section 7 concludes the paper.

\section{Related literature and hypotheses development}

\section{$2.1 \quad$ Related literature}

Existing studies on domestic and foreign investors' stock ownership can be primarily grouped into two broad categories: (i) a comparative analysis of investment performance of domestic and foreign investors, and (ii) an analysis of the determinants of institutional ownership. Studies in the first category analyze whether domestic investors are better informed and earn higher returns than foreign investors. Brennan and Cao (1997), for instance, find that US investors tend to purchase foreign equities when foreign market returns are high. Similarly, Brennan et al. (2005) show that global financial institutions are more optimistic if the foreign market return increases, and vice versa. These findings support the presumption that foreign investors are less informed, since they react to lagged information.

Grinblatt and Keloharju (2000) and Seasholes (2000), on the other hand, argue that FIIs should perform better than DIIs because of access to superior expertise and talent. By examining investors' tendency to buy future winning and sell future losing stocks, Grinblatt and Keloharju (2000) show evidence of foreign investors outperforming local investors. They report that domestic investors, presumably less sophisticated, take the opposite position to that of more sophisticated foreign investors. Seasholes (2000) also finds that foreign investors react more appropriately by buying (selling) before a positive (negative) earning surprise and consequently earn above market returns. On the other hand, Choe et al. (2005) and Hau (2001) document that 
individual domestic investors have an informational advantage over foreign investors. Choe et al. (2005) find that foreign investors buy at higher and sell at lower intraday prices than domestic investors. Hau (2001) reports that foreign traders earn significantly lower profits than domestic ones. Likewise, Dvořák (2005) shows that domestic investors do better than foreign investors, as they earn higher profits compared to foreign investors.

The second strand of literature (i.e. the determinants of institutional ownership) shows the differing preferences of foreign and domestic investors. Dahlquist and Robertsson (2001) show that foreign investors prefer the firms that pay lower dividends, are larger in size, and are holding larger cash balances. Lin and Shiu (2003) find that foreign investors favor larger firms and low book-to-market stocks. Both Dahlquist and Robertsson (2001) and Lin and Shiu (2003) also find that foreign investors, possibly due to their different tax status, hold slightly more stocks with low dividend yield. Ko et al. (2007) also find that foreign investors have a clearer preference for stocks with large capitalization and low book-to-market ratios than do DIIs in both the Japanese and Korean stock markets. Gompers and Metrick (2001) find that foreign institutional investors favor value stocks. Badrinath et al. (1996) and Falkenstein (1996) show that institutional investors prefer stocks that have higher market liquidity and lower return volatility. More recent studies also show that investors have a preference for firms with better governance structure. Doidge et al. (2009) and Leuz et al. (2010) for US institutions, and Ferreira and Matos (2008) for global institutions, find a negative relation between large block ownership by insiders and institutional holdings. Giannetti and Simonov (2006) show that institutional investors avoid companies that have high control to cash flow rights of principal shareholders. Both Bushee et al. (2014) and Chung and Zhang (2011) also robustly document a positive relation between institutional holdings and the quality of governance structure. 
In summary, several existing studies compare the investment patterns of foreign and domestic investors and explore the determinants of institutional ownership in public firms, especially in the context of secondary markets. This study analyses these two issues in the context of IPOs.

\subsection{Hypotheses development}

The above summary of the literature shows that there is no unanimous evidence on which of the two types of investors (foreign or domestic) is better informed, and neither do the studies agree on the factors that influence the investment decisions of domestic and foreign investors. Grinblatt and Keloharju (2000) attribute the superior performance of foreign investors to their investment experience and expertise. On the other hand, Kang and Stulz (1997) and Choe et al. (2005) suggest that the better performance of domestic investors is due to their informational advantage over foreign investors.

Relative to DIIs, FIIs are likely to face an informational disadvantage in most markets. However, in India FIIs should be able to find and use the information available on the participation of other investors, particularly DIIs, prior to making their own subscription decision. ${ }^{7}$ In spite of such reduced information asymmetry, however, DIIs may still have superior information due to their local knowledge. On the other hand, FIIs possess wider investment experience and superior expertise, which should enable them to identify and invest in 'good'

\footnotetext{
${ }^{7}$ Since 2007 Indian IPO regulators have also required issuers to grade the offering, using independent credit rating agencies. The availability of ratings should further reduce the information asymmetry for IPO investors. We re-ran all our analyses using a smaller sample of IPOs that have IPO grading. Our results remain qualitatively similar.
} 
quality IPOs. Therefore, on balance, there ought to be no substantial information asymmetry between the FIIs and DIIs and we hypothesize that 'there should be no significant difference in the investment patterns and performance of DIIs and FIIs in India.' To test this hypothesis we analyze three empirical issues. First, we provide a comparative analysis of the level of subscriptions of FIIs and DIIs. Second, we examine and identify the determinants of initial returns of both FIIs and DIIs. Third, post-listing holdings of FIIs and DIIs are analyzed to assess their flipping behavior.

To examine whether DIIs or FIIs subscribe to more IPOs, we analyze their subscriptions at the time of the issue and their holdings immediately after the listing. If both groups of investors (FIIs and DIIs) have the same level of information their subscription rates should not differ significantly. An analysis of the holdings of FIIs and DIIs in the post-listing period will also enable us to assess whether FIIs are return chasers. We examine the determinants of the initial returns of the IPO firms to test whether DIIs or FIIs are superior in IPO selection. Analysis of these three research issues, collectively, should help address our main research issue of whether there is any information asymmetry between the FIIs and DIIs to test the prediction that 'there should be no significant difference in the investment patterns and performance of DIIs and FIIs in India.'

\section{Data and summary statistics}

\section{[Insert Table 1 about here]}

\subsection{Data}

The sample is comprised of 329 IPOs listed on the BSE and/or NSE of India between January 2004 and December 2013. Table 1 shows how we arrived at the sample of IPOs for the 
study. The total number of IPOs issued during the sample period is 461 , of which 110 are fixed price offerings. As stated earlier (footnote 5), since we are unable to track the participation of institutional investors in fixed-price offerings, we exclude them from our analysis. In line with prior IPO literature and also because they are substantially larger than the average IPO, we exclude 19 privatization, financial and utilities IPOs. We also exclude 3 IPOs because of missing data. The data on firm and IPO characteristics are extracted from the IPO prospectus. The market data as well as the data on the subscriptions of DIIs and FIIs are collected from the BSE website (www.bseindia.com). For IPOs with missing institutional subscription data on the BSE, we collect institutional allocation data from an IPO portal (Chittorgarh; www.chittorgarh.com $)^{8}$ to construct the institutional subscription variable.

Appendices B-1 and B-2 show how we use data from the above mentioned websites to construct DIIs' and FIIs' subscriptions. Appendix B-1 shows institutional subscription data available on the BSE website. Panel A shows the information available on the website and Panel B shows how we construct the variables of interest. We construct domestic and foreign subscriptions by dividing their respective subscriptions by the total shares reserved for the institutional investor category. For IPOs with information missing on the BSE website, we construct the institutional subscription variable by using institutional allocation and the overall institutional subscription data. Since allocation is on a pro rata basis for the majority of our sample firms, we use allocation and the overall times subscribed to construct the institutional subscription. Panel A of Appendix B-2 shows the allocation for one of our sample firms and Panel B shows how we construct our variable of interest. As above, we again construct domestic and foreign subscriptions by dividing their respective subscriptions by the total shares reserved

\footnotetext{
${ }^{8}$ Chittorgarh is considered to be India's primary IPO investment portal.
} 
for the institutional investor category. Indian firms are required to submit their shareholding pattern to the SEBI on a quarterly basis, showing the holdings of different investor categories, including DIIs and FIIs. This information is publicly available on the BSE website. Data on total institutional holdings, as well as for DIIs and FIIs, is taken from the Capitaline database ${ }^{9}$ and we verify its accuracy by randomly cross-checking some data with those available on the BSE website.

\section{[Insert Table 2 about here]}

\subsection{Summary Statistics}

Table 2 provides summary statistics of firms and offers, market-related and institutional subscription variables of our sample of 329 IPOs. Appendix A provides definitions of all the variables used in the study. Panel A reports summary statistics related to investor subscription at the time of the IPO. The average (median) total subscription is $18.81(5.78)$ times whereas the average (median) total institutional subscription is 21.84 (6.22) times, which shows that IPOs in India are well subscribed by investors. The mean (median) subscription by DIIs and FIIs is 9.15 (2.40) and 12.45 (3.12) times respectively. Both mean and median differences are statistically significant at the less than $1 \%$ significance level. ${ }^{10}$ This suggests that FIIs' subscription is much higher than DIIs' at the time of the offering. To better understand this participation of DIIs and FIIs, in Panel D we report the statistics on IPOs that are subscribed vs. those that are not subscribed by institutional investors. As shown, DIIs completely avoid 54 of the 329 IPOs

\footnotetext{
${ }^{9}$ www.capitaline.com

${ }^{10}$ We run the paired t-test and the Wilcoxon signed rank sum test to test the difference between domestic and foreign institutional subscriptions respectively.
} 
(16.41\%), a figure which is twice as high as the 27 IPOs (8.20\%) completely avoided by FIIs. Further, FIIs avoid only 11 of the 54 IPOs avoided by DIIs. Thus, it appears that FIIs do not freeride on the publicly available information on DIIs subscription. Moreover, in spite of being exposed to the same level of officially disclosed information, the investment patterns of FIIs and DIIs differ significantly, with FIIs possibly relying more on their access to superior analytical skills and wider experience, while DIIs depend on their local knowledge.

Panels B and C of Table 2 report summary statistics related to firm, offer and marketrelated variables. Overall, the average (median) size of the firms measured by their total assets is INR $7,361(1,895)$ and the average (median) market capitalization based on the offer price is INR $22,576(3,926)$ million. ${ }^{11}$ Similarly, the average (median) age and debt of the sample are 14.33 (12) years and 56\% (61\%) respectively. Promoters' (founders') ownership pre-IPO and post-IPO averages about $56 \%$ and $23 \%$ respectively. The average (median) return on assets (ROA) (for the full year prior to IPO) is 9\% (7\%) and the average (median) percentage of cash and marketable securities to total assets is $32 \%(1 \%)$. Likewise, the average (median) book-tomarket value is around $0.55(0.41)$. The average (median) underwriter reputation, which equals 1 for reputable underwriters, is 0.58 (1) which shows the majority of the IPOs during the sample period are managed by reputable underwriters. The average (median) market-adjusted first day return for our sample of firms is $19 \%(9 \%)$.

\section{Determinants of Institutional Subscription}

We begin our empirical analysis by examining the determinants of IPO subscription for DIIs and FIIs, using an OLS regression framework as shown in Equation (1) below. The main

\footnotetext{
${ }^{11}$ US\$ 1 was approximately equal to INR 45 (on average) during our sample period.
} 
dependent variable is institutional investors' subscription. We define institutional subscription as the ratio of the shares bid to the shares reserved for the institutional investor category. Appendix A provides definitions of all the variables used in the study. As is the norm in the IPO literature (see Cornelli and Goldreich, 2003; Neupane and Poshakwale, 2012) and to smooth out the excessive effect of the variable, we use the logarithm of one plus the institutional investors' subscription in our specifications.

$$
\begin{aligned}
& \text { Institutional Investors'subscription } \\
& =\alpha+\beta_{1} \text { Market Capilization }+\beta_{2} \text { Book to Market }+\beta_{3} \text { Firm Age } \\
& +\beta_{4} R O A+\beta_{5} \text { Cash }+\beta_{6} \text { Leverage }+\beta_{7} \text { Investment Opportunities } \\
& +\beta_{8} \text { Promoters' Post IPO Holdings }+\beta_{9} \text { Underwriter Reputation } \\
& +\beta_{10} \text { Market Return }+\beta_{11} \text { Market Volatility }+\sum_{k=1}^{11} \beta_{k} \text { Industry } \\
& +\sum_{j=1}^{12} \beta_{j} Y e a r+\varepsilon
\end{aligned}
$$

The inclusion of firm, IPO and market specific variables in Equation (1) are motivated by the economic explanations and empirical evidence documented in existing studies. The literature suggests that institutional investors are attracted to larger (log of market capitalization), more mature (log of age) and growth (low book-to-market ratios) firms (see Gompers and Metrick, 2001; Ferreira and Matos, 2008; Chung and Zhang, 2011). Similarly, studies also suggest that institutional holdings are positively related to firms' returns (ROA), cash holdings and investment opportunities, while they are negatively related to higher leverage and insiders' holdings (i.e. promoters' post-IPO holdings) (Ferreira and Matos, 2008; Chung and Zhang, 2011). It has also been noted that institutional holdings are influenced by stock return and 
volatility. We account for such conjecture by including the overall market return and market volatility at the time of the IPO. As Field and Lowry (2009) report a positive relation between institutional holdings and the reputation of the underwriter, we also include underwriters' reputation as one of the explanatory variables. The models also control for year and industry fixed effects. ${ }^{12}$

We present the results of three different specifications of Equation (1) in Table 3. The dependent variable of specification (1) is the logarithm of one plus the overall institutional investors' subscription. In specification (2) the dependent variable is the logarithm of one plus DIIs' subscription. Finally, in specification (3) the dependent variable is the logarithm of one plus FIIs' subscription.

\section{[Insert Table 3 about here]}

The estimates in specification 1 (Table 3) show that the total institutional subscription is positively related to the market capitalization of the firm and cash holdings. This suggests that larger and more profitable firms with higher liquid assets receive higher institutional interest than smaller and less profitable firms with fewer liquid assets. This is consistent with the findings reported in Falkenstein (1996) and Gompers and Metrick (2001) for the US market, and in Dahlquist and Robertsson (2001) for the Swedish market. Further, total institutional subscription is also positively related to underwriter's reputation and recent market return. This implies that institutional participation is significantly higher in IPOs managed by underwriters with a high reputation and is also likely to be higher in periods following high recent market returns. On the other hand, institutional participation is negatively related to promoters' post-IPO

\footnotetext{
${ }^{12}$ We control for industry effects by classifying firms in 11 different industry categories.
} 
holdings, which indicates that institutional investors subscribe less in firms with large-block ownerships by insiders (Ferreira and Matos, 2008). Higher holdings are associated with concentrated control rights, and there is considerable evidence that institutions invest less in firms with large-block ownership by insiders (i.e. promoters) (Doidge et al., 2009; Leuz et al., 2010). We also find a negative relation between institutional subscription and recent market volatility. The negative coefficient suggests that institutional investors become less inclined to participate in IPOs at times of high market volatility. The coefficients of firm age, book-tomarket ratio, ROA, leverage and investment opportunities are not significant.

Next, we separately examine the subscriptions of DIIs and FIIs, and report the results in specifications (2) and (3) respectively. Although most of the control variables appear to have a similar influence, we also find that while the coefficient of market volatility is significant for DIIs, it is not significant in the case of FIIs. In terms of economic significance, we find that when recent market volatility increases with an amount equal to $10 \%$ of its median value, the participation of DIIs decreases by about $4.5 \%$. The corresponding figure for FIIs is less than $1 \%$.

Further, whilst we find similar statistical significance in the control variables on the participation of DIIs and FIIs, our analysis shows that the level of economic significance varies. For instance, the market capitalization of the IPO firm, cash holdings and recent market return have greater influence on the subscription of FIIs than of DIIs. On the other hand, ROA and underwriter's reputation appears to have a greater influence on DIIs' subscription. Overall, our results show that while there are similarities in the subscriptions by DIIs and FIIs in relation to market capitalization, cash holdings and promoters' post-IPO holdings, there are also some differences, most notably in relation to market volatility at the time of the offering. 


\section{[Insert Table 4 about here]}

\section{Institutional subscription and IPO returns}

This section examines the influence of DIIs' and FIIs' subscriptions on initial listing returns. Prior studies (Field and Lowry, 2009; Chiang et al., 2010) have shown that institutional investors are better informed and hence their participation is positively related to IPO listing performance. We contribute to the literature by examining the impact of subscription by DIIs and FIIs, first separately and then jointly, on their listing period returns.

We estimate six different specifications of equation (2) and the results are presented in Table 4. The dependent variable in specifications (1) to (4) is the first day market-adjusted return. The dependent variables in specifications (5) and (6) are the market-adjusted returns of the first week and the first month respectively. The market-adjusted return is the difference between raw IPO returns and the corresponding market returns. We use the BSE Sensex index to estimate market returns.

IPO Initial Returns

$$
\begin{aligned}
& =\alpha+\beta_{1} \text { Institutional Subscription }+\beta_{2} \text { DIIs Subscription } \\
& +\beta_{3} \text { FIIs Subscription }+\beta_{4} \text { Market Capitalization }+\beta_{5} \text { Firm Age } \\
& +\beta_{6} \text { Underwriter Reputation }+\beta_{7} \text { Market Return } \\
& +\beta_{8} \text { Market Volatility }+\sum_{k=1}^{11} \beta_{k} \text { Industry }+\sum_{j=1}^{12} \beta_{j} \text { Year }+\varepsilon
\end{aligned}
$$

In Equation (2), our main explanatory variables of interest are alternative measures of institutional subscription. In specifications (1) - (3) the variables of interest are overall institutional subscription (logarithm of one plus overall institutional subscription), DIIs' 
subscription (logarithm of one plus DIIs' subscription) and FIIs' subscription (logarithm of one plus FIIs' subscription) respectively. Specifications (4) - (6) include both DIIs' and FIIs' subscriptions. We also control for a number of factors that have been identified in prior studies (Field and Lowry, 2009; Chiang et al., 2010). They include: log of market capitalization, log of one plus the age of the firm, a dummy variable for the reputation of the underwriter managing the IPO. Following Derrien and Womack (2003), we also include market return and market volatility at the time of IPO. ${ }^{13}$ The regressions also control for year and industry fixed effects. Appendix A provides definitions of all the variables used in the study.

As noted earlier, in specifications (1) - (3) we separately examine the influence of overall institutional, domestic and foreign subscription respectively on first day market-adjusted returns. The results show a strong relation between first day return and all the three institutional subscription variables. Consistent with previous studies we also find that the initial return is negatively related to both market capitalization and underwriter reputation. Since the impact of recent market return and market volatility is already incorporated in institutional subscription, the coefficients of neither market return nor market volatility are statistically significant.

Specification (4) includes both DIIs' and FIIs' subscription. The estimates show that while the coefficient on DIIs' subscription remains positive and significant, the coefficient on FIIs' subscription loses its significance. The sign as well as the statistical significance of most of the other variables remains the same. This result suggests that DIIs' subscription is more influential and subsumes the impact of FIIs' subscription in explaining first day market returns. Given the evidence on subscription that we show in the previous section, this evidence is not entirely surprising, since DIIs' subscription appears to be more measured as well as more varied

\footnotetext{
${ }^{13}$ For detailed descriptions of the economic arguments for their inclusion, refer to the studies mentioned.
} 
compared to that of FIIs. Importantly, when taken together the evidence on subscription and initial returns suggests that by not considering the publicly available information on DIIs' subscription, FIIs' investment appears to be plagued by informational disadvantage.

Further diagnostic tests are carried out to examine whether specification (4) is plagued by collinearity. We calculate variance inflation factors (VIFs) for variables included in specification (4). The VIFs for DIIs' and FIIs' subscription variables are 3.38 and 3.65 respectively. Since these figures are below the threshold of 5 that is commonly used in the literature (Hogan et al., 2001), we argue that standard interpretations of the regression coefficients can be made for results presented in specification (4).

In specifications (5) and (6), we re-run specification (4) by replacing the dependent variable with first week and first month market-adjusted returns respectively. The unreported results show that separately the coefficients of both DIIs' and FIIs' subscriptions are positive and statistically significant. However, as with first day returns, only DIIs' subscription remains statistically significant when both DIIs' and FIIs' subscriptions are included in the same specification. VIF for specifications (5) and (6) for domestic and foreign institutional subscription variables are similar to those reported in specification (4).

Overall, the results discussed above demonstrate that the subscription of institutional investors is positively related to post-listing returns, demonstrating their stock picking abilities. Importantly, however, our findings suggest that in the context of Indian IPOs, the degree of participation by DIIs, which appears to be measured and varied, has a greater influence on postlisting returns than the participation of FIIs. 


\section{[Insert Table 5 about here]}

\section{Post-IPO holdings of Institutional Investors}

This section examines institutional investors' holdings in the immediate post-listing period. We extend the analysis of DIIs and FIIs beyond the IPO subscription stage for two reasons. First, prior studies (Aggarwal, 2003; Ellis, 2006) suggest that investors flip a significant portion of their allocation in the immediate post-listing period. Thus, a subscription at the time of the IPO may only reflect an interest on the part of the investor in making a quick return rather than investing on the basis of sound company fundamentals. Grinblatt and Keloharju (2000) and Bohn and Tesar (1996) suggest that FIIs represent hot money chasing hot markets. Second, institutional investors subscribing to Indian IPOs are only required to deposit $10 \%$ of the bid amount at the time of subscription. Hence, institutional investors may oversubscribe, relative to their investable funds, at the time of the IPO in order to improve their allocations. Thus, given these two aspects of IPO subscription, we further examine institutional holdings through univariate and multivariate analysis for two calendar quarters after the date of listing.

\subsection{Univariate Analysis}

Table 5 reports univariate statistics on institutional investors' holdings at the time of allocation (column 1), at the end of the first quarter (column 2) and at the end of the second quarter (column 3). The figures show the mean (median) percentage of shares held by institutional investors relative to the total outstanding shares. Such holdings are reported first for overall institutional investors and then separately for DIIs and FIIs. Panel A reports institutional 
holdings for the total sample of IPOs and Panel B reports institutional holdings by first day return quartiles.

As shown in Panel A, the overall median IPO has a total institutional ownership of $13.76 \%$ at the time of allocation, which declines to $10.21 \%$ and $10.25 \%$ at the end of the first and second quarters respectively. Consistent with evidence from previous studies (Aggarwal, 2003; Ellis, 2006), evidence in Table 5 indicates that institutional investors reduce their holding in IPO firms in the post-listing period. The mean (median) decline of $3.68 \%(3.55 \%)$ from the date of allocation to the end of the first quarter is statistically significant. ${ }^{14}$ Since FIIs subscribe more at the time of the IPO, their holdings in the median overall IPO at the time of the allocation is $7.33 \%$, which is $2.40 \%$ higher than the DIIs' holding in the median overall IPO. Interestingly, we also find that FIIs reduce their holdings more than DIIs in the post-listing period. Between the date of allocation and the end of the first quarter, FIIs reduce their holdings by $2.40 \%$ in the median overall IPO. DIIs, by comparison, reduce their holdings by only $1.16 \%$. Institutional investors' holdings appear to remain steady in the period beyond the first quarter. The median DIIs' holdings are $3.34 \%$ and $3.07 \%$ at the end of the first and second quarters respectively. The corresponding figures for FIIs are $4.93 \%$ and $4.73 \%$ respectively.

In Panel B we report institutional holdings by quartiles of first day returns for four different IPO categories: cold IPOs $(n=82$ and mean first day return $=-22.04 \%)$; cool IPOs $(n=82$ and mean first day return $=-0.002 \%)$; warm IPOs $(\mathrm{n}=83$ and mean first day return $=23.43 \%)$; and hot IPOs ( $\mathrm{n}=82$ and mean first day return $=76.20 \%$ ). The analysis of institutional holdings by

\footnotetext{
${ }^{14}$ It should be noted that while the sum of mean domestic and foreign institutional holdings will add up to total mean institutional holdings, the sum of median domestic and foreign institutional holdings will not add up to total median institutional holdings.
} 
first day return quartiles presents a number of interesting observations. Overall, we find that institutional investors reduce their holdings the most in the weaker (cold and cool) offerings, with the median holdings declining in cold IPOs from $14.39 \%$ at allocation to $8.99 \%$ (a decline of 5.50\%) at the end of the first quarter. The corresponding decline in cool, warm and hot IPOs are $3.34 \%, 0.76 \%$ and $3.67 \%$ respectively. This evidence of institutional investors reducing their holdings in weaker IPOs is not consistent with the evidence from US IPOs (Aggarwal, 2003).

We also find significant differences in how FIIs and DIIs reduce their holdings in the postlisting period. The results suggest that while FIIs reduce their holdings more in weaker offerings, DIIs appear to do so in hot offerings. FIIs reduce their holdings from $8.01 \%$ at allocation to $2.85 \%$ at the end of the first quarter in the median cold IPO, a decline of $5.16 \%$, with the difference statistically significant at the less than $1 \%$ significance level. The corresponding decline in DIIs' holdings is only $0.76 \%$. FIIs reduce their holdings by $2.23 \%, 1.97 \%$ and $1.57 \%$ in cool, warm and hot IPOs respectively. DIIs, on the other hand, reduce their holdings the most in the hot IPOs. They only hold $1.56 \%$ in the median hot IPO at the end of the first quarter after the listing, down from $4.40 \%$ at the time of allocation.

Overall, the univariate analysis suggests that DIIs and FIIs not only exhibit different investment strategies at the time of subscription, but also in the post-listing period. This evidence is consistent with Grinblatt and Keloharju (2000), who show that domestic investors take a different position compared to that of FIIs. While our analysis does not divulge which of these two investor categories performs better over the long-term, our evidence with respect to subscription, post-listing performance and post-listing holdings suggests that FIIs appear to be more aggressive and short-term oriented than DIIs. 


\section{[Insert Table 6 about here]}

\subsection{Multivariate Analysis}

In this sub-section we examine post-IPO institutional holdings in a multiple regression framework. Given that institutional investors may oversubscribe at the time of offering, we first re-examine the determinants of institutional holdings using shareholding data as at the end of the first quarter after listing. Second, since our univariate analysis above shows significant changes in institutional holdings from the date of allocation to the end of the first quarter after listing, we examine the determinants of such change. The results of this analysis are presented in Table 6 .

Specifications (1), (2) and (3) in Table 6 replicate the analysis presented in Table 3 by replacing institutional oversubscription with institutional holdings at the end of the first quarter of listing as the dependent variable. Further, we use all the independent variables as specified in Equation (1) other than replacing the market return and market volatility with stock return and stock volatility variables. We make a few notable observations on the comparison of the two results. While some variables lose their significance, others become stronger in explaining institutional holdings. The insignificant coefficient of market capitalization for domestic institutional holdings suggests that domestic investors are equally likely to hold stocks in both large and small companies, while foreign investors show a strong preference for the larger firms. The statistical significance of the coefficient of promoters' post-IPO holdings (concentrated insiders' holdings) is much stronger with first quarter holdings. Further, both DIIs and FIIs are likely to hold shares of firms that are mature and established. The observed change in significance of some variables from IPO subscription to first quarter holdings is consistent with 
the findings of Ellis (2006), who argues that long-term investors may adjust their position following IPO allocation by either flipping or accumulating in the period after the offering.

In specifications (4), (5) and (6), we re-run the regressions by using the change in institutional holdings (from allocation to the end of the first quarter) as the dependent variable. This analysis sheds light on the factors that drive institutional investors to adjust their position in the period following the allocation of shares. Results show that the five factors that influence changes in institutional holdings in the immediate period after the IPO are: age of the firm, cash holdings, underwriter reputation, stock return and volatility. While only one of these factors is significant in explaining the change in DIIs' holdings (specification 5), all five factors are significant for explaining the change in FIIs' holdings. This is, perhaps, due to the fact that the change in DIIs' holdings is far less than the change in FIIs' holdings in the post-listing period. The results also show that FIIs reduce their holdings in firms that are younger, less profitable and have lower cash holdings. Stock return and volatility also appear to influence the change in institutional holdings, as FIIs reduce their holdings in firms with poor post-listing stock returns and higher stock volatility. These results are largely consistent with Ferreira and Matos (2008) and Chung and Zhang (2011).

\section{Robustness Tests}

In this section we conduct a number of robustness tests to confirm the validity of our results. ${ }^{15}$

\subsection{Using only auction IPOs}

As mentioned earlier (footnote 5), our sample includes both book-building and auction IPOs. One of the main changes in IPO regulation when it moved from a book-building to an

\footnotetext{
${ }^{15}$ The results of all these robustness tests can be made available upon request.
} 
auction mechanism was the removal of allocation discretion in the institutional investor category. Prior research has shown that underwriters' discretion in allocation influences how investors subscribe to IPO shares (Jenkinson and Jones, 2009). To address the issue that the change in regulation (from discretion to pro-rata allocation) may have influenced how investors participate in auction relative to book-building IPOs, we re-ran all our analyses (IPO subscription, analysis of IPO returns and post-IPO holdings) using only auction IPOs. All of our results remain qualitatively similar.

\subsection{Alternative time windows for post-IPO holding analysis}

Our post-IPO holding analysis uses data up to the end of the first quarter of listing. For robustness purposes we extend this analysis and examine institutional holdings up to the end of the first year of listing. We find that institutional holdings remain reasonably stable after the first quarter. Mean (median) total, domestic and foreign institutional holdings at the end of the first year after listing are $11.05 \%(10.98 \%), 4.79 \%(2.86 \%)$ and $6.45 \%(4.47 \%)$ respectively. We reran the post-IPO holdings multivariate analysis using the end of the first year holdings and find that all results remain qualitatively similar to the ones reported in Table 6 .

\subsection{Alternative measures of the variables used in the study}

To ensure that our results are robust to how we measure the variables, we re-ran the analysis by employing alternative measures of some of the explanatory variables of primary interest. Instead of using market capitalization and book-to-market variables based on the offer price, we re-ran the analysis using variables calculated on the basis of the stock price at the end of the first day of listing and the price at the end of the first month. Results remain qualitatively 
similar. Additionally, we use only long-term debt in calculating the leverage ratio as an alternative specification of the variable. Similarly, when we examine institutional holdings at the end of the first year of holdings we use stock return and stock volatility variables based on daily returns in the first year of listing. None of these specifications alter the quality of findings presented in the earlier section.

\section{Conclusions}

Using a dataset of 329 firms, this study examines the investment behavior of DIIs and FIIs in IPOs in the context of the Indian market. The study uncovers a number of interesting findings. By examining institutional subscriptions at the time of IPO, we find that FIIs are more aggressive and subscribe significantly more to IPOs than do DIIs. The results also show that different economic determinants which in the prior literature are associated with institutional investment have an asymmetric influence on the subscriptions of both FIIs and DIIs. Since investment by DIIs seems more measured and varied than that by FIIs, the study finds that domestic institutional subscription is significantly more influential in explaining listing and immediate post-listing returns.

Given that the extant literature suggests that investors flip a significant portion of IPO allocation, we also examine the immediate post-listing period holding patterns of DIIs and FIIs. The results show that FIIs not only subscribe more at the time of the IPO, but they also appear to reduce their holdings more than DIIs in the immediate post-listing period. DIIs and FIIs also exhibit differences in the types of firm in which they reduce their holdings, with the former reducing holdings considerably more in hot IPOs, while the latter appear to do the same in cold IPOs. Overall, in spite of the regulatory provisions that allow all investors to have the same level 
of information, the investment patterns and stock selection of FIIs and DIIs differ significantly. Consequently, our main prediction that 'there should be no significant difference in the investment patterns and performance of DIIs and FIIs in India' is not supported. Possibly the difference in the investment patterns and stock selection of FIIs and DIIs results from their differences in experience, access to expert skills and local knowledge.

A potential limitation of this study is related to wider generalization. Since the study is based on the unique setting of the Indian IPO market, the findings may not be helpful to investors in less transparent markets. Nevertheless, the findings of this study have important implications for uninformed retail investors in India. Neupane and Poshakwale (2012) show that retail investors can do well in IPO investment in India by following the participation of institutional investors. Our evidence shows that it would be more prudent for retail investors to follow the investment of DIIs as they appear to be more measured and informed in their IPO subscriptions. Since subscription by different investor categories, including DIIs, is available publicly during the offering period, retail investors can use this information to improve on their investment performance. Whilst the regulatory provisions are helpful in reducing information asymmetry among the various categories of investors, local knowledge seems to remain valuable in investment decisions. This implies that although FIIs have access to superior expertise and experience they could still benefit by extracting signals from the participation levels of DIIs. 


\section{References}

Aggarwal, R., 2003. Allocation of initial public offerings and flipping activity. Journal of Financial Economics 68, 111-135.

Badrinath, S.G., Kale, J.R., Ryan, H.E.J., 1996. Characteristics of Common Stock Holdings of Insurance Companies. Journal of Risk and Insurance 63, 49-76.

Bohn, H., Tesar, L.L., 1996. US equity investment in foreign markets: portfolio rebalancing or return chasing? The American Economic Review, 77-81.

Brennan, M.J., Cao, H.H., 1997. International portfolio investment flows. Journal of Finance 52, 1851-1880.

Brennan, M.J., Cao, H.H., Strong, N., Xu, X., 2005. The dynamics of international equity market expectations. Journal of Financial Economics 77, 257-288.

Bushee, B.J., Carter, M.E., Gerakos, J., 2014. Institutional investor preferences for corporate governance mechanisms. Journal of Management Accounting Research 26, 123149.

Chiang, Y., Qian, Y., Sherman, A., 2010. Endogenous entry and partial adjustment in IPO auctions: Are institutional investors better informed? Review of Financial Studies 23, 12001230 .

Choe, H., Kho, B., Stulz, R.M., 2005. Do domestic investors have an edge? the trading experience of foreign investors in Korea. The Review of Financial Studies 18, 795-829.

Chung, K.H., Zhang, H., 2011. Corporate governance and institutional ownership. Journal of Financial and Quantitative Analysis 46, 247-273.

Cornelli, F., Goldreich, D., 2003. Bookbuilding: How informative is the order book? Journal of Finance 58, 1415-1443.

Dahlquist, M., Robertsson, G., 2001. Direct foreign ownership, institutional investors, and firm characteristics. Journal of Financial Economics 59, 413-440.

Derrien, F., Womack, K.L., 2003. Auctions vs. Bookbuilding and the Control of Underpricing in Hot IPO Markets. Review of Financial Studies 16, 31-61.

Doidge, C., Karolyi, G.A., Lins, K.V., Miller, D.P., Stulz, R.M., 2009. Private benefits of control, ownership, and the cross - listing decision. The Journal of Finance 64, 425-466.

Dvořák, T., 2005. Do domestic investors have and information advantage? Evidence from Indonesia. The Journal of Finance 60, 817-839. 
Ellis, K., 2006. Who trades IPOs? A close look at the first days of trading. Journal of Financial Economics 79, 339-363.

Falkenstein, E.G., 1996. Preferences for Stock Characteristics as Revealed by Mutual Fund Portfolio Holdings. Journal of Finance 51, 111-135.

Ferreira, M.A., Matos, P., 2008. The colors of investors' money: The role of institutional investors around the world. Journal of Financial Economics 88, 499-533.

Field, L., Lowry, M., 2009. Institutional versus individual investment in IPOs: the importance of firm fundamentals. Journal of Financial and Quantitative Analysis 44, 489516.

Giannetti, M., Simonov, A., 2006. Which investors fear expropriation? Evidence from investors' portfolio choices. The Journal of Finance 61, 1507-1547.

Gompers, P., Metrick, A., 2001. Institutional investors and equity prices. Quarterly Journal of Economics 116, 229-259.

Grinblatt, M., Keloharju, M., 2000. The investment behavior and performance of various investor types: a study of Finland's unique data set. Journal of Financial Economics 55, 4357.

Hau, H., 2001. Location matters: an examination of trading profits. Journal of Finance 56, 1959-1983.

Hogan, K.M., Olson, G.T., Kish, R.J., 2001. A comparison of reverse leveraged buyouts and original initial public offers: factors impacting their issuance in the IPO market. Financial Review 36, 1-18.

Jenkinson, T., Jones, H., 2009. IPO pricing and allocation: a survey of the views of institutional investors. Review of Financial Studies 22, 1477-1504.

Kang, J.-K., Stulz, R., 1997. Why is there a home bias? An analysis of foreign portfolio equity ownership in Japan. Journal of Financial Economics 46, 3-28.

Ko, K., Kim, K., Cho, S.H., 2007. Characteristics and performance of institutional and foreign investors in Japaneseand Korean stock markets. Journal of the Japanese and International Economies 21, 195-213.

Leuz, C., Lins, K.V., Warnock, F.E., 2010. Do foreigners invest less in poorly governed firms? Review of Financial Studies 23, 3245-3285.

Lin, C.H., Shiu, C.Y., 2003. Foreign ownership in the Taiwan stock market--an empirical analysis. Journal of Multinational Financial Management 13, 19-41. 
Neupane, S., Poshakwale, S., 2012. Transparency in IPO Mechanism: Retail investors' participation, IPO pricing and returns. Journal of Banking and Finance 36, 2064-2076.

Seasholes, M.S., 2000. Smart foreign traders in emerging market. Unpublished Work, University of California, Berkely. 


\section{Appendix A}

Description of variables used in the study

\begin{tabular}{|c|c|}
\hline Variables & Definition \\
\hline \multicolumn{2}{|c|}{ Institutional subscription/holdings variables } \\
\hline Total Subscription & $\begin{array}{l}\text { The ratio of total shares bid by all investors to the total number } \\
\text { of shares offered }\end{array}$ \\
\hline Institutional Subscription & $\begin{array}{l}\text { The ratio of total shares bid by the institutional investors to the } \\
\text { total number of shares offered to institutional investors }\end{array}$ \\
\hline Domestic Subscription & $\begin{array}{l}\text { The ratio of total shares bid by the DIIs to the total number of } \\
\text { shares offered to institutional investors }\end{array}$ \\
\hline Foreign Subscription & $\begin{array}{l}\text { The ratio of total shares bid by the FIIs to the total number of } \\
\text { shares offered to institutional investors }\end{array}$ \\
\hline Total Institutional Holdings & $\begin{array}{l}\text { The percentage of shares held by total institutional investors } \\
\text { relative to the total shares outstanding }\end{array}$ \\
\hline Domestic Holdings & $\begin{array}{l}\text { The percentage of shares held by DIIs relative to the total shares } \\
\text { outstanding }\end{array}$ \\
\hline Foreign Holdings & $\begin{array}{l}\text { The percentage of shares held by FIIs relative to the total shares } \\
\text { outstanding }\end{array}$ \\
\hline \multicolumn{2}{|l|}{ Firm and offer variables } \\
\hline Total Assets & $\begin{array}{l}\text { Book value of total assets at the time of the IPO (logarithm of } \\
\text { total assets) }\end{array}$ \\
\hline Proceeds & $\begin{array}{l}\text { Gross proceeds of the offer calculated by multiplying the offer } \\
\text { price by the number of shares offered }\end{array}$ \\
\hline Market Capitalization & $\begin{array}{l}\text { The total market capitalization of the firm based on the offer } \\
\text { price (logarithm of market capitalization) }\end{array}$ \\
\hline Age & $\begin{array}{l}\text { Difference between a firm's IPO year and the founding year } \\
\text { (logarithm of } 1 \text { plus the firm's age) }\end{array}$ \\
\hline Promoters' Pre-IPO Holdings & $\begin{array}{l}\text { The ratio of the shares held by promoters (founders) to the total } \\
\text { outstanding shares before the IPO }\end{array}$ \\
\hline Promoters' Post-IPO Holdings & $\begin{array}{l}\text { The ratio of the shares held by promoters' (founders) to the total } \\
\text { outstanding shares after the IPO }\end{array}$ \\
\hline Leverage & The ratio of total debt to total assets at the time of the IPO \\
\hline ROA & $\begin{array}{l}\text { The return on total assets for the full year prior to the year of the } \\
\text { IPO }\end{array}$ \\
\hline Cash & The ratio of cash and marketable securities to total assets at the \\
\hline
\end{tabular}


Book-to-Market

Stock Return

Stock Volatility

Investment Opportunities

Underwriter Reputation

Market-adjusted First Day

Return

Market Return

Market Volatility

Cold IPO time of the IPO.

The ratio of the book-to-market value of equity (calculated at the offer price) at the time of the IPO offer

Annualized return based on the average daily stock returns for the first three months of listing, excluding the return on the first day of listing

Standard deviation of the daily returns for the first three months of listing, excluding the first day of listing

Geometric average growth rate in sales in the three years prior to the year of the IPO

The binary variable which equals 1 for reputable underwriters and 0 otherwise. We categorize as reputable those underwriters who have managed at least INR 10,000 million during the sample period (Neupane and Poshakwale, 2012).

Difference between raw first day return and market return, where the market return is the return on the BSE Sensex index over the same period. Raw first day return is the simple return calculated between the offer price and the closing price at the end of the first day of trading.

The weighted average of the buy-and-hold returns on the BSE Sensex index in the three months prior to the IPO issue opening date $\mathrm{t}$; the weights being 3 for the month before the IPO date $\left(\mathrm{M}_{\mathrm{t}-1}\right), 2$ for the month before that $\left(\mathrm{M}_{\mathrm{t}-2}\right)$, and 1 for the third month before the offering $\left(\mathrm{M}_{\mathrm{t}-3}\right)$

The standard deviation of the market returns one month prior to the issue opening date

Dummy variable that takes a value of 1 if IPO first day return is below negative and 0 otherwise. 


\section{Appendix B-1}

\section{Ashoka Buildcon (From the BSE Website)}

Panel A: Information available from the website

\begin{tabular}{|l|l|r|r|r|}
\hline \multicolumn{1}{|c|}{$\#$} & \multicolumn{1}{|c|}{ Category } & $\begin{array}{c}\text { No. of shares } \\
\text { offered/reserved }\end{array}$ & No. of shares bid for & Times Subscribed \\
\hline 1 & \multicolumn{1}{|c|}{ Institutional Investors } & $\mathbf{3 , 1 6 5 , 9 0 9}$ & $\mathbf{8 0 , 7 9 2 , 5 6 5}$ & $\mathbf{2 5 . 5 2}$ \\
\hline $\mathbf{1 ( a )}$ & FIIs & & $45,078,915$ & \\
\hline $\mathbf{1 ( b )}$ & $\begin{array}{l}\text { Domestic Financial Institutions } \\
\text { (Banks/ Financial Institutions } \\
\text { (FIs)/ Insurance Companies) }\end{array}$ & & $14,523,173$ & \\
\hline $\mathbf{1 ( c )}$ & Mutual Funds & & $2,142,335$ & \\
\hline $\mathbf{1 ( d )}$ & Others & & & \\
\hline
\end{tabular}

\section{Panel B: Construction of Subscription Variable}

\begin{tabular}{|l|l|l|l|}
\hline Category & Domestic & Foreign & Total \\
\hline No. of Shares reserved for Institutional Investors & & & $3,165,909$ \\
\hline No. of Shares bid & $35,713,650$ & $45,078,915$ & $80,792,565$ \\
\hline Times Subscribed (Shares bid/Reserved for Institutional Investors) & 14.24 & 11.28 & 25.52 \\
\hline
\end{tabular}

\section{Appendix B-2}

\section{Blue Bird India Ltd (From Chittorgarh Website)}

Panel A: Information available from the website

\section{Allocation to Institutional Investors}

\begin{tabular}{|l|l|l|l|}
\hline Category & Domestic Institutional Investors & Foreign Institutional Investors & Total \\
\hline No. of Equity Shares & $1,765,780$ & $2,621,720$ & $\mathbf{4 , 3 8 7 , 5 0 0}$ \\
\hline
\end{tabular}

\section{Panel B: Construction of Subscription Variable}

\begin{tabular}{|l|l|l|l|}
\hline Category & Domestic & Foreign & Total \\
\hline No. of Equity Shares Allocated & $1,765,780$ & $2,621,720$ & $4,387,500$ \\
\hline No. of Shares Reserved for Institutional Investors & & & $1,512,930$ \\
\hline No. of Times Subscribed by Institutional Investors & & & 2.90 \\
\hline No. of Shares bid (Allocation × Overall Times Subscribed) & $5,120,762$ & $7,602,988$ & \\
\hline Times Subscribed (Shares bid/Reserved for Institutional Investors) & 1.73 & 1.17 & \\
\hline
\end{tabular}


Table 1

Sample Selection

Total IPOs issued between January 2004 and December 2013

less: fixed price offerings

less: privatization, financial and utility IPOs

less : IPOs with missing data 
Table 2

Summary Statistics

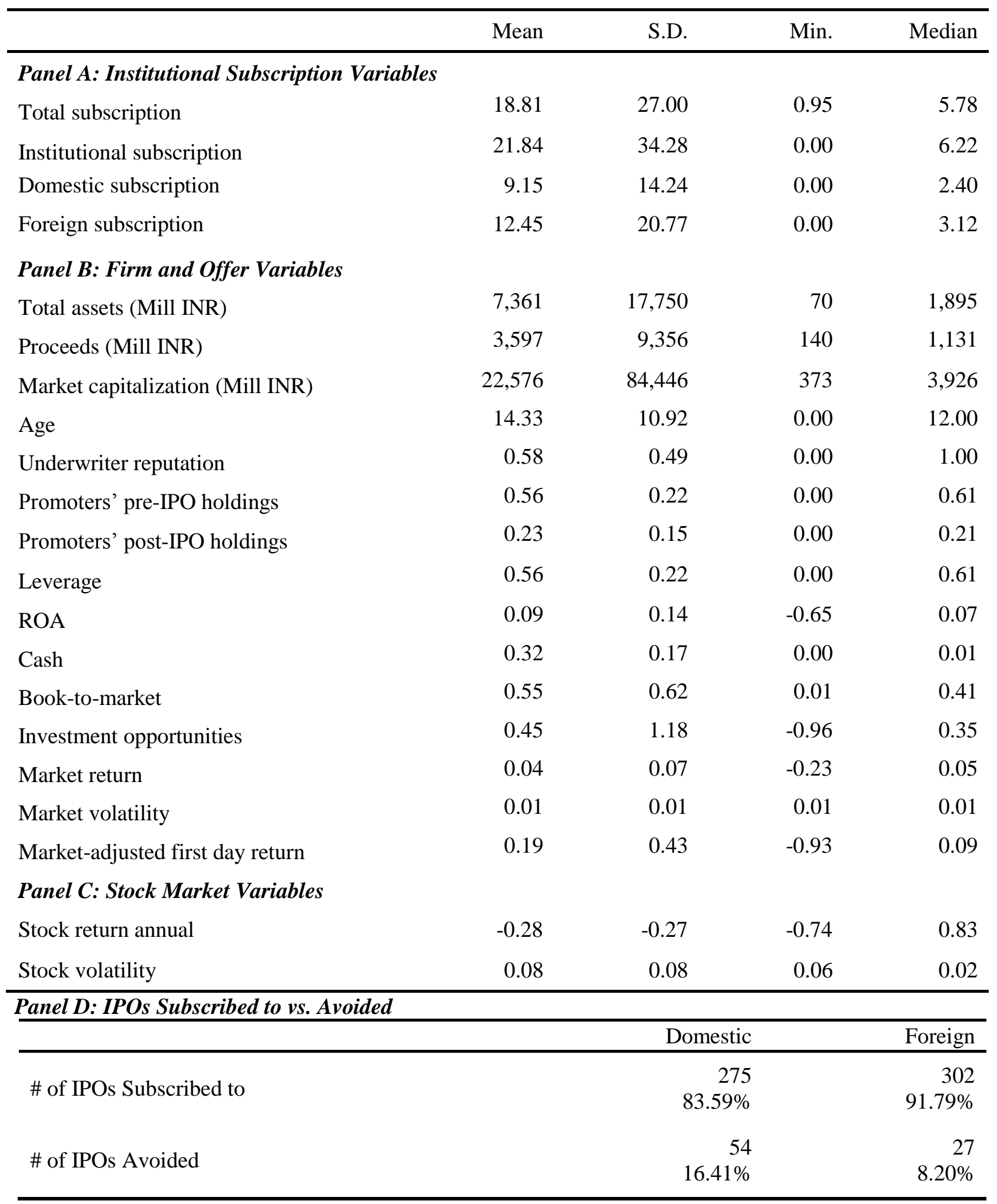

This table reports the descriptive statistics of Indian IPO characteristics along with subscription details. The sample includes IPOs listed on the BSE and NSE between January 2004 and December 2013. All the variables are defined in Appendix A. There are only 11 IPOs in which both DIIs and FIIs have avoided subscription. 
Table 3

Determinants of foreign and domestic institutional investors' subscription at the IPO

\begin{tabular}{|c|c|c|c|}
\hline & $\begin{array}{c}\text { Total } \\
(1)\end{array}$ & $\begin{array}{l}\text { Domestic } \\
\text { (2) }\end{array}$ & $\begin{array}{c}\text { Foreign } \\
(3)\end{array}$ \\
\hline Log Market Capitalization & $\begin{array}{c}0.311 * * * \\
(4.32)\end{array}$ & $\begin{array}{c}0.206 * * * \\
(3.12)\end{array}$ & $\begin{array}{c}0.307 * * * \\
(4.82)\end{array}$ \\
\hline Book-to-Market & $\begin{array}{l}0.043 \\
(0.40)\end{array}$ & $\begin{array}{l}0.055 \\
(0.57)\end{array}$ & $\begin{array}{l}0.014 \\
(0.13)\end{array}$ \\
\hline Log Age & $\begin{array}{l}0.119 \\
(1.04)\end{array}$ & $\begin{array}{l}0.152 \\
(1.51)\end{array}$ & $\begin{array}{l}0.069 \\
(0.66)\end{array}$ \\
\hline ROA & $\begin{array}{l}0.628 \\
(1.35)\end{array}$ & $\begin{array}{l}0.721 \\
(1.32)\end{array}$ & $\begin{array}{l}0.620 \\
(1.37)\end{array}$ \\
\hline Cash & $\begin{array}{c}0.744 * * * \\
(4.62)\end{array}$ & $\begin{array}{c}0.681 * * * \\
(2.83)\end{array}$ & $\begin{array}{c}0.691 * * * \\
(5.82)\end{array}$ \\
\hline Leverage & $\begin{array}{l}-0.319 \\
(-0.80)\end{array}$ & $\begin{array}{l}-0.300 \\
(-0.84)\end{array}$ & $\begin{array}{l}-0.157 \\
(-0.43)\end{array}$ \\
\hline Investment Opportunities & $\begin{array}{l}0.020 \\
(0.56)\end{array}$ & $\begin{array}{l}0.036 \\
(1.02)\end{array}$ & $\begin{array}{l}0.010 \\
(0.26)\end{array}$ \\
\hline Promoter's Post-IPO holdings & $\begin{array}{c}-0.943 * * \\
(-1.98)\end{array}$ & $\begin{array}{c}-0.829 * \\
(-1.90)\end{array}$ & $\begin{array}{c}-0.761^{*} \\
(-1.78)\end{array}$ \\
\hline Underwriter Reputation & $\begin{array}{c}0.528 * * * \\
(2.64)\end{array}$ & $\begin{array}{c}0.591 * * * \\
(3.18)\end{array}$ & $\begin{array}{c}0.371 * * \\
(2.09)\end{array}$ \\
\hline Market Return & $\begin{array}{c}4.497 * * * \\
(3.94)\end{array}$ & $\begin{array}{c}3.907 * * * \\
(3.67)\end{array}$ & $\begin{array}{c}4.301 * * * \\
(4.17)\end{array}$ \\
\hline Market Volatility & $\begin{array}{c}-15.308^{*} \\
(-1.77)\end{array}$ & $\begin{array}{c}-20.348^{* *} \\
(-2.42)\end{array}$ & $\begin{array}{l}-3.079 \\
(-0.22)\end{array}$ \\
\hline Industry \& Year Fixed Effects & Yes & Yes & Yes \\
\hline Constant & $\begin{array}{r}-1.029 \\
(-1.40) \\
\end{array}$ & $\begin{array}{r}-0.576 \\
(-0.81) \\
\end{array}$ & $\begin{array}{c}-1.939 * * * \\
(-2.89) \\
\end{array}$ \\
\hline $\begin{array}{l}\text { Observations } \\
\text { Adjusted } R^{2}\end{array}$ & $\begin{array}{c}329 \\
0.473\end{array}$ & $\begin{array}{c}329 \\
0.417\end{array}$ & $\begin{array}{c}329 \\
0.457\end{array}$ \\
\hline
\end{tabular}

This table shows the OLS regression results for the determinants of the subscription of total institutional investors, FIIs, and DIIs. The sample includes IPOs listed on the BSE and NSE from January 2004 to December 2013. All the variables are defined in Appendix A. White's heteroskedasticity-consistent t-statistics are in parentheses. *p<0.10, $* * \mathrm{p}<0.05, * * * \mathrm{p}<0.01$ 
Table 4

Institutional Subscription and IPO returns

\begin{tabular}{|c|c|c|c|c|c|c|}
\hline & (1) & (2) & (3) & (4) & $(5)$ & (6) \\
\hline Log Institutional subscription & $\begin{array}{c}0.200 * * * \\
(9.51)\end{array}$ & & & & & \\
\hline Log Domestic subscription & & $\begin{array}{c}0.218 * * * \\
(8.96)\end{array}$ & & $\begin{array}{c}0.189 * * * \\
(3.38)\end{array}$ & $\begin{array}{c}0.241 * * * \\
(3.86)\end{array}$ & $\begin{array}{c}0.291 * * * \\
(4.10)\end{array}$ \\
\hline Log Foreign subscription & & & $\begin{array}{c}0.188 * * * \\
(8.02)\end{array}$ & $\begin{array}{l}0.034 \\
(0.67)\end{array}$ & $\begin{array}{l}0.003 \\
(0.05)\end{array}$ & $\begin{array}{l}-0.016 \\
(-0.28)\end{array}$ \\
\hline Log Market Capitalization & $\begin{array}{c}-0.054 * * * \\
(-2.82)\end{array}$ & $\begin{array}{c}-0.043 * * \\
(-2.24)\end{array}$ & $\begin{array}{c}-0.052 * * * \\
(-2.60)\end{array}$ & $\begin{array}{c}-0.046 * * \\
(-2.32)\end{array}$ & $\begin{array}{l}-0.029 \\
(-1.28)\end{array}$ & $\begin{array}{l}-0.017 \\
(-0.63)\end{array}$ \\
\hline Log Age & $\begin{array}{l}-0.027 \\
(-0.81)\end{array}$ & $\begin{array}{l}-0.037 \\
(-1.11)\end{array}$ & $\begin{array}{l}-0.016 \\
(-0.47)\end{array}$ & $\begin{array}{l}-0.034 \\
(-1.02)\end{array}$ & $\begin{array}{l}-0.030 \\
(-0.79)\end{array}$ & $\begin{array}{l}-0.055 \\
(-1.23)\end{array}$ \\
\hline Underwriter Reputation & $\begin{array}{c}-0.208 * * * \\
(-3.69)\end{array}$ & $\begin{array}{c}-0.219 * * * \\
(-3.88)\end{array}$ & $\begin{array}{c}-0.169 * * * \\
(-2.86)\end{array}$ & $\begin{array}{c}-0.218 * * * \\
(-3.88)\end{array}$ & $\begin{array}{c}-0.255^{* * *} \\
(-3.71)\end{array}$ & $\begin{array}{c}-0.252 * * * \\
(-2.71)\end{array}$ \\
\hline Market Return & $\begin{array}{l}0.251 \\
(0.55)\end{array}$ & $\begin{array}{l}0.264 \\
(0.59)\end{array}$ & $\begin{array}{l}0.353 \\
(0.74)\end{array}$ & $\begin{array}{l}0.240 \\
(0.53)\end{array}$ & $\begin{array}{l}0.319 \\
(0.67)\end{array}$ & $\begin{array}{l}0.179 \\
(0.36)\end{array}$ \\
\hline Market Volatility & $\begin{array}{l}8.128 \\
(1.51)\end{array}$ & $\begin{array}{l}9.477 \\
(1.53)\end{array}$ & $\begin{array}{l}5.926 \\
(1.06)\end{array}$ & $\begin{array}{l}8.990 \\
(1.58)\end{array}$ & $\begin{array}{l}4.932 \\
(0.89)\end{array}$ & $\begin{array}{l}-1.046 \\
(-0.18)\end{array}$ \\
\hline Industry \& Year Fixed Effects & Yes & Yes & Yes & Yes & Yes & Yes \\
\hline Constant & $\begin{array}{c}0.587 * * * \\
(2.66)\end{array}$ & $\begin{array}{c}0.589 * * * \\
(2.65)\end{array}$ & $\begin{array}{c}0.714 * * * \\
(3.06)\end{array}$ & $\begin{array}{c}0.613^{* * *} \\
(2.73)\end{array}$ & $\begin{array}{c}0.509 * * \\
(2.23)\end{array}$ & $\begin{array}{c}0.508 * \\
(1.74)\end{array}$ \\
\hline Observations & 329 & 329 & 329 & 329 & 329 & 329 \\
\hline Adjusted $R^{2}$ & 0.292 & 0.288 & 0.232 & 0.287 & 0.287 & 0.298 \\
\hline
\end{tabular}


This table shows the OLS regression results for determinants of the IPO return. In specifications (1) - (4), the dependent variable is the market-adjusted first day IPO return and in specifications (5) and (6) the dependent variable is market-adjusted first week and first month IPO returns respectively. The sample includes IPOs listed on the BSE and NSE from January 2004 to December 2013. All the variables are defined in Appendix A. White's heteroskedasticity-consistent tstatistics are in parentheses. ${ }^{*} \mathrm{p}<0.10, * * \mathrm{p}<0.05, * * * \mathrm{p}<0.01$ 
Table 5

Univariate Analysis: Post-IPO Institutional Holdings

\begin{tabular}{|c|c|c|c|c|c|c|c|}
\hline & $\begin{array}{c}\text { At allocation } \\
\text { (1) }\end{array}$ & $\begin{array}{l}\text { 1st quarter } \\
\text { post-listing } \\
\text { (2) }\end{array}$ & $\begin{array}{c}\text { 2nd quarter } \\
\text { post-listing } \\
\text { (3) }\end{array}$ & $\begin{array}{c}\text { Difference } \\
(2-1) \\
(4)\end{array}$ & $\begin{array}{c}\text { p-value } \\
(5)\end{array}$ & $\begin{array}{c}\text { Difference } \\
(3-2) \\
(6)\end{array}$ & $\begin{array}{c}\text { p-value } \\
(7)\end{array}$ \\
\hline \multicolumn{8}{|l|}{ Panel A: Holdings for total IPOs } \\
\hline Domestic & $6.26(4.95)$ & $5.13(3.34)$ & $4.91(3.07)$ & $-1.13(-1.61)$ & $0.009(0.000)$ & $-0.22(-0.27)$ & $0.045(0.007)$ \\
\hline Foreign & $8.88(7.33)$ & $6.33(4.93)$ & $6.69(4.73)$ & $-2.55(-2.40)$ & $0.000(0.000)$ & $0.36(-0.20)$ & $0.143(0.008)$ \\
\hline Difference (Domestic - Foreign) & $-2.61(-2.38)$ & $-1.20(-1.59)$ & $-1.78(-1.66)$ & & & & \\
\hline \multicolumn{8}{|c|}{ Panel B: Holdings by first day return quartiles } \\
\hline \multicolumn{8}{|c|}{ Cold IPOs $(n=82)$} \\
\hline Total institutional & $13.64(14.39)$ & $9.63(8.99)$ & $9.44(9.71)$ & $-4.01(-5.50)$ & $0.000(0.000)$ & $-0.19(0.82)$ & $0.552(0.243)$ \\
\hline Domestic & $5.99(4.10)$ & $4.75(3.32)$ & $4.41(3.01)$ & $-1.24(-0.76)$ & $0.000(0.000)$ & $-0.34(-0.33)$ & $0.010(0.003)$ \\
\hline Foreign & $7.65(8.01)$ & $4.88(2.85)$ & $5.03(2.25)$ & $-2.77(-5.16)$ & $0.000(0.000)$ & $0.15(-0.60)$ & $0.649(0.613)$ \\
\hline \multicolumn{8}{|l|}{ Cool IPOs $(n=82)$} \\
\hline Total institutional & $15.48(13.45)$ & $11.13(10.11)$ & $11.40(10.31)$ & $-4.35(-3.34)$ & $0.000(0.000)$ & $0.27(0.20)$ & $0.591(0.749)$ \\
\hline Domestic & $6.93(5.21)$ & $5.31(3.52)$ & $4.93(3.21)$ & $-1.62(-1.69)$ & $0.000(0.000)$ & $-0.21(-0.00)$ & $0.037(0.008)$ \\
\hline Foreign & 8.55 (7.09) & $5.82(4.86)$ & $6.47(5.47)$ & $-2.73(-2.23)$ & $0.000(0.000)$ & $0.65(0.61)$ & $0.158(0.057)$ \\
\hline Difference (Domestic - Foreign) & $-1.62(-1.88)$ & $-0.51(-1.34)$ & $-1.54(-2.26)$ & & & & \\
\hline p-value & $0.115(0.048)$ & $0.549(0.380)$ & $0.089(0.066)$ & & & & \\
\hline \multicolumn{8}{|l|}{ Warm IPOs $(n=83)$} \\
\hline Total institutional & $15.90(13.71)$ & $13.86(12.95)$ & $14.46(12.73)$ & $-2.04(-0.76)$ & $0.044(0.083)$ & $0.60(-0.22)$ & $0.446(0.025)$ \\
\hline Domestic & $5.99(5.48)$ & $5.73(4.33)$ & $5.75(4.38)$ & $-0.26(-1.15)$ & $0.554(0.321)$ & $0.02(0.05)$ & $0.895(0.741)$ \\
\hline Foreign & $9.91(7.72)$ & $8.13(5.75)$ & $8.71(6.65)$ & $-1.78(-1.97)$ & $0.040(0.061)$ & $0.58(0.90)$ & $0.471(0.025)$ \\
\hline
\end{tabular}




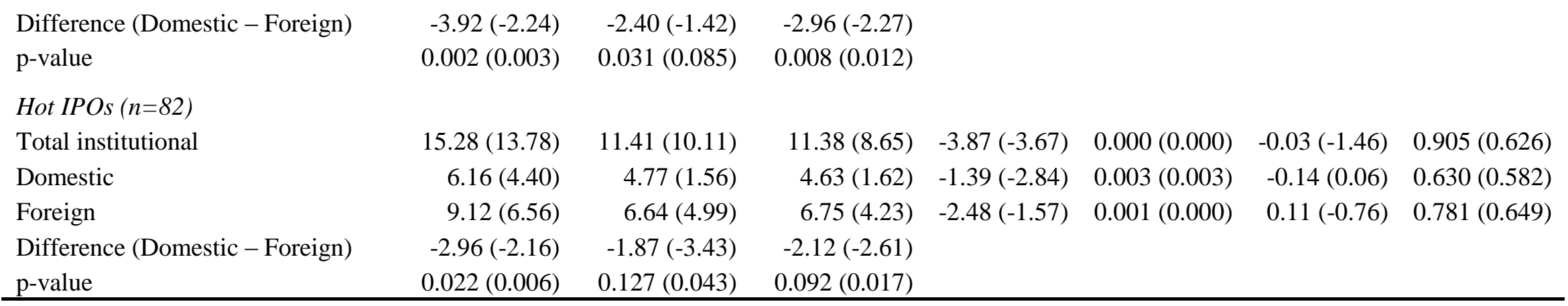

This table reports the univariate statistics of institutional holdings immediately after allocation (column 1), first quarter (column 2) and second quarter (column 3) after listing. The figures represent the percentage of holdings relative to total shares outstanding. Total institutional, domestic and foreign respectively refer to total institutional, domestic institutional and foreign institutional holdings. Column (4) shows the difference between first quarter holdings and the holdings immediately after allocation while column (6) shows the difference between second and first quarter holdings. Columns (5) and (7) show the p-values of the $t$-test (z-test) for the difference in mean (median) for change in institutional holdings between the two periods. The sample includes IPOs listed on the BSE and NSE from January 2004 to December 2013. All the variables are defined in Appendix A. 


\section{Table 6}

Multivariate Regression Analysis: Post IPO Institutional Holdings

\begin{tabular}{|c|c|c|c|c|c|c|}
\hline & \multicolumn{3}{|c|}{ At the End of the First Quarter } & \multicolumn{3}{|c|}{ Change (First Quarter - Allocation) } \\
\hline & $\begin{array}{l}\text { Total } \\
\text { (1) }\end{array}$ & $\begin{array}{l}\text { Domestic } \\
\text { (2) }\end{array}$ & $\begin{array}{l}\text { Foreign } \\
\text { (3) }\end{array}$ & $\begin{array}{c}\text { Total } \\
\text { (4) }\end{array}$ & $\begin{array}{l}\text { Domestic } \\
\text { (5) }\end{array}$ & $\begin{array}{l}\text { Foreign } \\
\text { (6) }\end{array}$ \\
\hline Log Market Capitalization & $\begin{array}{c}1.476^{* * * *} \\
(2.76)\end{array}$ & $\begin{array}{l}0.105 \\
(0.34)\end{array}$ & $\begin{array}{c}1.368 * * * \\
(3.37)\end{array}$ & $\begin{array}{l}0.280 \\
(0.57)\end{array}$ & $\begin{array}{l}-0.204 \\
(-0.56)\end{array}$ & $\begin{array}{l}0.479 \\
(1.42)\end{array}$ \\
\hline Book-to-Market & $\begin{array}{l}-0.053 \\
(-0.07)\end{array}$ & $\begin{array}{l}0.168 \\
(0.35)\end{array}$ & $\begin{array}{l}-0.223 \\
(-0.38)\end{array}$ & $\begin{array}{l}-0.675 \\
(-1.41)\end{array}$ & $\begin{array}{l}-0.529 \\
(-1.61)\end{array}$ & $\begin{array}{l}-0.144 \\
(-0.28)\end{array}$ \\
\hline Log Age & $\begin{array}{c}1.700^{* *} \\
(2.13)\end{array}$ & $\begin{array}{c}1.335 * * * \\
(3.16)\end{array}$ & $\begin{array}{l}0.363^{*} \\
(1.86)\end{array}$ & $\begin{array}{c}2.392 * * * \\
(3.43)\end{array}$ & $\begin{array}{l}0.771^{*} \\
(1.67)\end{array}$ & $\begin{array}{c}1.614 * * * \\
(3.17)\end{array}$ \\
\hline ROA & $\begin{array}{l}3.776 \\
(1.26)\end{array}$ & $\begin{array}{l}1.487 \\
(0.79)\end{array}$ & $\begin{array}{l}2.296 \\
(0.99)\end{array}$ & $\begin{array}{l}-0.132 \\
(-0.04)\end{array}$ & $\begin{array}{l}-4.401 \\
(-1.34)\end{array}$ & $\begin{array}{c}4.255^{* *} \\
(2.03)\end{array}$ \\
\hline Cash & $\begin{array}{c}8.379 * * * \\
(4.76)\end{array}$ & $\begin{array}{c}9.905 * * * \\
(3.32)\end{array}$ & $\begin{array}{l}1.530^{*} \\
(1.87)\end{array}$ & $\begin{array}{l}1.667 \\
(1.56)\end{array}$ & $\begin{array}{l}0.618 \\
(0.49)\end{array}$ & $\begin{array}{c}2.288 * * * \\
(3.14)\end{array}$ \\
\hline Leverage & $\begin{array}{l}-1.789 \\
(-0.62)\end{array}$ & $\begin{array}{l}-0.548 \\
(-0.31)\end{array}$ & $\begin{array}{l}-1.222 \\
(-0.57)\end{array}$ & $\begin{array}{l}0.100 \\
(0.05)\end{array}$ & $\begin{array}{l}-0.019 \\
(-0.01)\end{array}$ & $\begin{array}{l}0.137 \\
(0.07)\end{array}$ \\
\hline Investment Opportunities & $\begin{array}{l}-0.020 \\
(-0.05)\end{array}$ & $\begin{array}{l}0.025 \\
(0.12)\end{array}$ & $\begin{array}{l}-0.041 \\
(-0.18)\end{array}$ & $\begin{array}{l}0.263 \\
(1.22)\end{array}$ & $\begin{array}{l}0.110 \\
(0.76)\end{array}$ & $\begin{array}{l}0.160 \\
(0.71)\end{array}$ \\
\hline Promoter's Post-IPO Holdings & $\begin{array}{c}-13.516^{* * *} \\
(-3.91)\end{array}$ & $\begin{array}{c}-5.517 * * \\
(-2.28)\end{array}$ & $\begin{array}{c}-8.097 * * * \\
(-2.93)\end{array}$ & $\begin{array}{l}2.935 \\
(0.90)\end{array}$ & $\begin{array}{l}2.443 \\
(0.94)\end{array}$ & $\begin{array}{l}0.413 \\
(0.15)\end{array}$ \\
\hline Underwriter Reputation & $\begin{array}{c}3.918 * * * \\
(2.68)\end{array}$ & $\begin{array}{c}1.757 * * \\
(2.11)\end{array}$ & $\begin{array}{c}2.159^{*} \\
(1.94)\end{array}$ & $\begin{array}{l}2.092^{*} \\
(1.81)\end{array}$ & $\begin{array}{l}0.022 \\
(0.03)\end{array}$ & $\begin{array}{c}2.067 * * \\
(2.54)\end{array}$ \\
\hline Stock Return & $\begin{array}{l}0.560 \\
(0.33)\end{array}$ & $\begin{array}{l}-0.244 \\
(-0.22)\end{array}$ & $\begin{array}{l}0.802 \\
(0.66)\end{array}$ & $\begin{array}{l}2.921^{*} \\
(1.94)\end{array}$ & $\begin{array}{l}0.153 \\
(0.20)\end{array}$ & $\begin{array}{c}2.762 * * \\
(2.26)\end{array}$ \\
\hline Stock Volatility & $\begin{array}{c}43.909 \\
(1.06)\end{array}$ & $\begin{array}{l}-7.307 \\
(-0.31)\end{array}$ & $\begin{array}{c}50.506 \\
(1.55)\end{array}$ & $\begin{array}{c}-105.730 * * * \\
(-2.90)\end{array}$ & $\begin{array}{l}-37.016 \\
(-1.24)\end{array}$ & $\begin{array}{c}-69.325 * * * \\
(-2.99)\end{array}$ \\
\hline Industry \& Year Dummy & Yes & Yes & Yes & Yes & Yes & Yes \\
\hline Constant & $\begin{array}{l}-6.218 \\
(-0.93) \\
\end{array}$ & $\begin{array}{l}3.967 \\
(0.85) \\
\end{array}$ & $\begin{array}{c}-10.092 * * \\
(-2.58) \\
\end{array}$ & $\begin{array}{c}-10.744 * * \\
(-2.53) \\
\end{array}$ & $\begin{array}{l}-1.302 \\
(-0.39) \\
\end{array}$ & $\begin{array}{c}-9.315^{* * * *} \\
(-3.26) \\
\end{array}$ \\
\hline $\begin{array}{l}\text { Observations } \\
\text { Adjusted } R^{2}\end{array}$ & $\begin{array}{c}329 \\
0.190\end{array}$ & $\begin{array}{c}329 \\
0.200\end{array}$ & $\begin{array}{c}329 \\
0.095\end{array}$ & $\begin{array}{c}329 \\
0.197\end{array}$ & $\begin{array}{c}329 \\
0.050\end{array}$ & $\begin{array}{c}329 \\
0.203\end{array}$ \\
\hline
\end{tabular}

Specifications (1) - (3) show the OLS regression results for institutional holdings in the first quarter after listing. Specifications (4) - (6) show the OLS regression results for the change in institutional holdings from the date of allocation to the end of the first quarter after listing. The sample includes IPOs listed on the BSE and NSE from January 2004 to December 2013. All the variables are defined in Appendix A. White's heteroskedasticity-consistent t-statistics are in parentheses. ${ }^{*} \mathrm{p}<0.10, * * \mathrm{p}<0.05, * * * \mathrm{p}<0.01$. 


\section{Domestic and Foreign Institutional Investors' Investment in IPOs}

\section{Highlights}

- We compare domestic \& foreign institutional investors' investment in IPOs.

- FIIs appear to be more aggressive in IPO subscription than DIIs.

- FIIs reduce their IPO holdings more deeply than DIIs in post-listing period.

- Evidence is consistent with the notion that FIIs chase hot markets with hot money. 